could succeed in hearing with it, but all with whom the experiment was successful preferred the card audiphone to that of ebonite.

A number of deaf mutes under the care of M. Sager, were blindfolded and provided with audiphones; the distances from a grand piano, at which they began to hear the sounds, indicated their different degrees of deafness. They could distinguish at once between the high and the low notes of the instrument, and between its tones and those of a violoncello. The shrillest tones of the violin produced little effect. Similar experiments were made by $M$. Colladon in another establishment for deaf-mutes, near Geneva, under the care of M. Forestier.

Mr. Thomas Fletcher, of Warrington, has communicated to us a further improvement. After a long series of experiments he has found the best material of which the audiphone can be made is birch-wood veneer. If cut to an oval about 12 inches by $8 \frac{1}{2}$, and steamed and bent to a curve, it does not require the cords of the Rhodes' pattern, and is more convenient for use than Colladon's form. Mr. Fletcher states that a disk of half the above size suffices for a musician who may, in consequence of partial deafness, require such aid, and who cannot use a hearing trumpet on account of the inconvenience of holding it while playing his instrument. The disk of veneer is so light that it may be held between the teeth without effort and almost without consciousness of its presence. If stained black it is less visible.

\section{THE ELASMOPODA (HYALMAR THEEL) A NEW ORDER OF HOLOTHURIDEA}

$A$ LTHOUGH the Holothuridea show a greater tendency $\mathrm{A}_{\text {to a bilateral arrangement of their internal organs than }}$ any other group of the Echinodermata, most of them are fusiform or cylindrical in shape, and the radiate symmetry prevails so far externally that the five radial ambulacral vessels and their appendages are similar, that they run symmetrically at equal distances from one another from the oral to the apical pole, and that they are used indifferently for the purposes of progression. In all Holothuridea, however, two ambulacra, those of the bivium, are essentially dorsal, while the three ambulacra of the trivium are ventral; and in one little group of the ordinary Dendrochirota, which includes the well-known genus Psolus, a very distinct ambulatory tract is defined

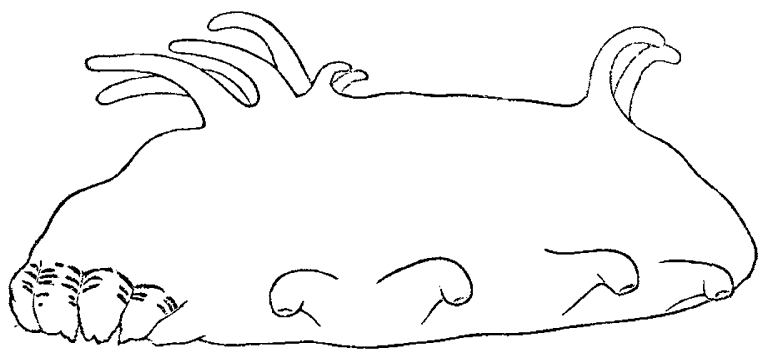

Fig. r.-Elpidia glacialis, Theel. Side view.

on the ventral surface of the body, and the pedicels of the rest of the ambulacral system are either absent or greatly modified. From the form of the ambulatory disk and the position of the mouth and apex, a Cuzieria, with its tentacles expanded, has a very striking resemblance to a large Doris.

In the year I875 Dr. Hjalmar Théel, attached as naturalist to Nordenskjöld's expedition to the Yenisei, dredged in the western portion of the Kara Sea at a depth of 150 fathoms, fourteen specimens of a small Holothurian, which he was at first inclined to take for a nudibranchiate mollusc. Elpidia glacialis, Théel, is about $20 \mathrm{~mm}$. long and $8 \mathrm{~mm}$. broad. The anterior por- tion is abruptly contracted, so as to give the appearance of a head, and the mouth, surrounded by a ring of ten tentacles, simple with the exception of two terminal papillæe, is turned downwards. A transverse section of the body is semicircular, the dorsal surface being strongly arched, while the ventral (trivial) surface is flat, and forms an ambulatory disk. The skin, which has the usual structure of the skin in the Holothuridea, is strengthened by a thick layer of felted calcareous spicules of different forms, with delicate branches which project through the skin, roughening it slightly. Very sparsely scattered, just below the epidermis, there are a few large wheels much like those of Myriotrochus, and a large number of very minute wheels are found in the outer layers of the skin. Elpidia has eight very prominent partially retractile pedicels or water-feet, placed in two opposite rows of four, on the lateral ambulacra of the trivium, along the edges of the ventral disk. Radial vessels are developed in two ambulacra only, the vessels of the ambulacra of the bivium and the central ambulacrum of the trivium being entirely suppressed. The nervous system is radially symmetrical, five cords running back symmetrically from the oral nerve ring along the five ambulacral lines. Otocysts of peculiar structure are placed at intervals along the course of the nerves.

On the back there are two rows of paired foot-like appendages much in the position of the bivial ambulacra; the appendages of the anterior group bend forwards, and those of the posterior backwards. From the absence of the bivial water-vessels these appendages are not in connection with the water-vascular system; they receive twigs, however, from the radial nerves.

Elpidia is unisexual; the small genital opening is placed in the dorsal middle-lines about mid-way between the crown of tentacles and the anterior group of dorsal appendages; the so-called "respiratory tree" and the Cuvierian glands are absent.

Elpidia is very remarkable both in external form and in internal structure, and differs widely both from the typical Pedata and from the Apoda, in many respects taking an intermediate place between these groups.

Since the appearance of Dr. Théel's paper Messrs. Koren and Danielssen have described in the Nyt Magazin for Naturvidenskaberne, two new genera procured by the Norwegian North-Sea Expedition, whose close relation to Elpidia is manifest. The characters of these genera will be given in their place in the systematic list.

On looking over the Holothuridea of the Challenger Expedition, I at once recognised the resemblance of a large number of the deep-sea species to the form which Dr. Theel had worked out with much care and skill, and acting under the advice of my friend, Prof. Lovén, 1 asked Dr. Théel to be good enough to undertake the description of the Challenger material belonging to the class, Prof. Lovén kindly offering his advice and assistance. Dr. Théel was over last summer and examined the collection. He recognised over 200 species, half of which are new to science, and of these the greater number from the deep-sea are related to Elpidia. The group enlarged to such an extent, and presenting so many marked peculiarities quite revolutionised the facies of the Holothuridea, and asserted itself as an order of value equal at all events to that of the PEDATA and APODA. For this order Dr. Théel proposes the name ELASMOPODA

Dr. Theel selected all the forms belonging to the new order in the Challenger collection, and carried them with him to Sweden, and a few weeks ago he published, with the permission of the Treasury, in the K. $\lrcorner \%$. Vet.-Akad. Handl. Band 5 , No. 19 , the first part of a preliminary report on the Holothuridea of the Challenger Expedition, in which seven new genera and seventeen new species of Elasmopoda are defined.

The following are the genera established by Dr. Théel, and $I$ add the definitions of the two others described by 
Koren and Danielssen to complete the sketch of the order according to our present knowledge.

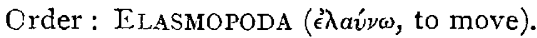

Body distinctly bilateral. Ambulacra well defined. The lateral ambulacra of the trivium bearing large, slightly retractile pedicels, disposed either in a single row, or sometimes in two rows, along each side of the ventral surface, and sometimes with another series of larger highly elongated not retractile processes placed externally and above the pedicels; pedicels of the two lateral ambulacra symmetrically arranged, being more or less distinctly opposed across the ventral surface. The odd ambulacrum naked or very seldom with a few rudimental pedicels. Bivium provided with very long not retractile processes, often disposed in one or more rows along each of its ambulacra and more or less distinctly opposed across the dorsal surface, or with only a few rudimental ones in its anterior part, or with a single very large one, resembling a broad, branched or unbranched lobe, and near to it some small papillæ. No respiratory trees. Integument naked, spiculous, or plated.

Deima, n.g., Figs. 2, 3 ( $\delta \epsilon i \mu a$, a fright).

Back highly convex; ventral surface flat. Mouth anterior, ventral; anus posterior, ventral. Tentacles small, perfectly retractile, about twenty (?). The lateral ambulacra of the trivium with large pedicels, slightly retractile at their ends alone, disposed in a single row all along each side of the ventral surface, and with another series of bighly elongated, conical, rigid, not retractile
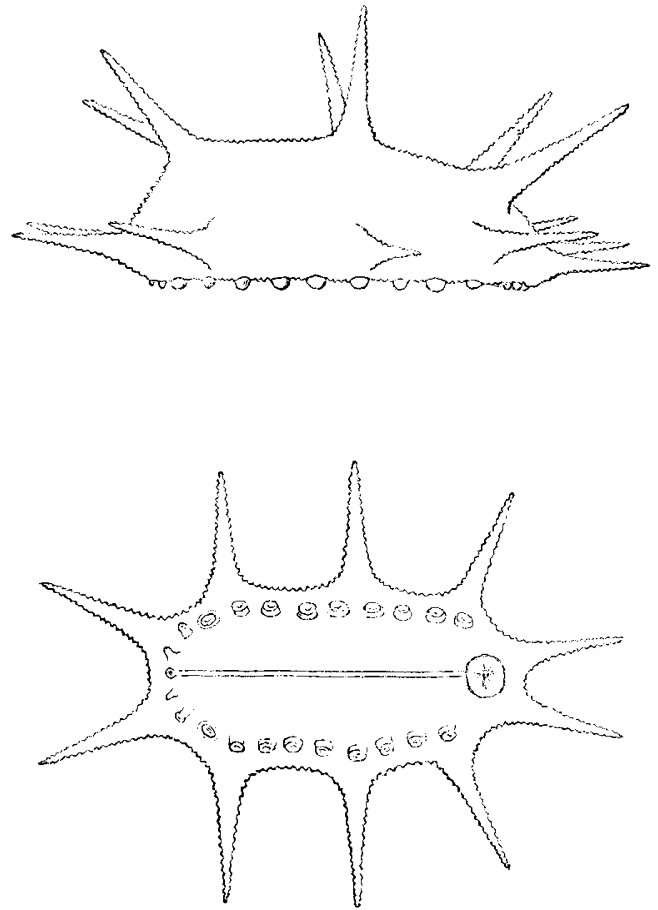

Figs, 2, 3.-Deima fastomın, Théel. Lateral and ventral views.

prosesses, placed externally and above the pedicels all along each side of the body and directed straight outwards. The odd ambulacrum naked. Bivium with processes, resembling those of the trivium, disposed in a single row all along each of its ambulacra. Processes forming transverse rows, more or less distinct. Integument with crowded, irregularly rounded, perforated plates.

$D$. validum, n.sp. D. fastorum.

Oneirophanta, n.g., Fig. 4 (ỏvє

Back highly convex; ventral surface flat. Mouth anterior, subventral ; anus posterior, ventral. Tentacles twenty, large and retractile at their ends alone. The lateral ambulacra of the trivium with large pedicels, slightly retractile at their ends, disposed in a double row all along each side of the ventral surface, and with another series of highly elongated, conical, more or less flexible, not retractile processes, placed externally and above the pedicels all along each side of the body. The

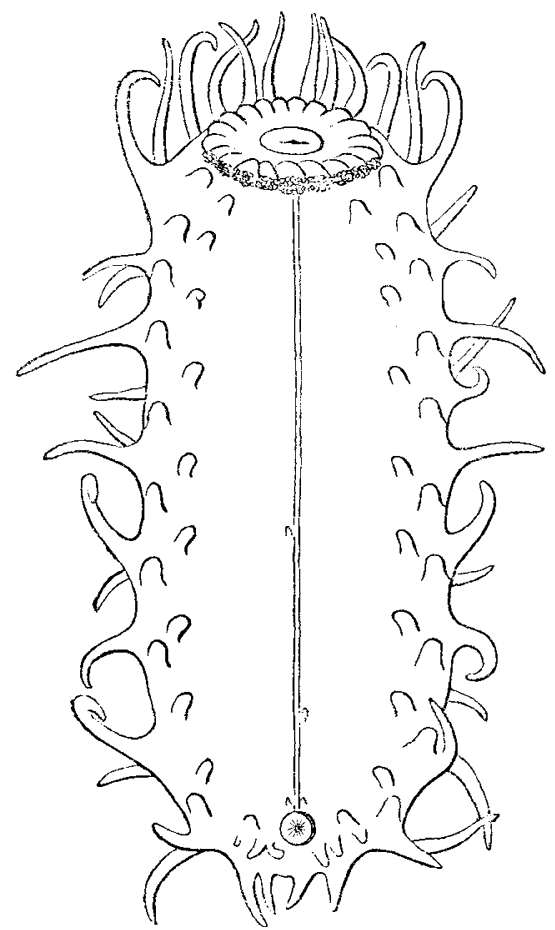

FIG. 4.-Oneirophanta mutabilis, Thél. Ventral surface.

odd ambulacrum, with a few more or less rudimental pediceis. Bivium with processes, resembling those of the trivium, disposed in a single row all along each of its ambulacra. Processes not forming transverse rows or very indistinct ones. Integument with crowded, irregularly rounded, perforated piates, often provided with minute processes.

O. mutabilis, n.sp.

Orphnurgus, n.g. (ö $\rho \phi \nu \eta$, darkness).

Back convex; ventral surface almost flat. Mouth anterior, terminal, subventral ; anus posterior, terminal, slightly dorsal. 'Tentacles twenty. The lateral ambulacra of the trivium with very large, not retractile pedicels, disposed in a single row all along each side of the ventral surface, and with another series of slender, very flexible, for the most part apparently retractile processes, placed above the pedicels all along each side of the body. The odd ambulacrum naked. Bivium with a crowded series of numerous processes, resembling those of the trivium, apparently disposed in two rows all along each of its ambulacra. Integument with spicula of various forms, but destitute of wheels.

O. asper, n.sp.

Cryodora, n.g. Fig. 5 (kpíos, cold).

Back highly convex; ventral surface almost flat. Mouth anterior, subventral; anus posterior, terminal, subdorsal. Tentacles fifteen. The lateral ambulacra of the trivium with large, slightly retractile pedicels, disposed in a single row all along each side of the ventral surface. The odd ambulacrum naked. Bivium with slender, flexible, not 
retractile processes, disposed in a single row all along

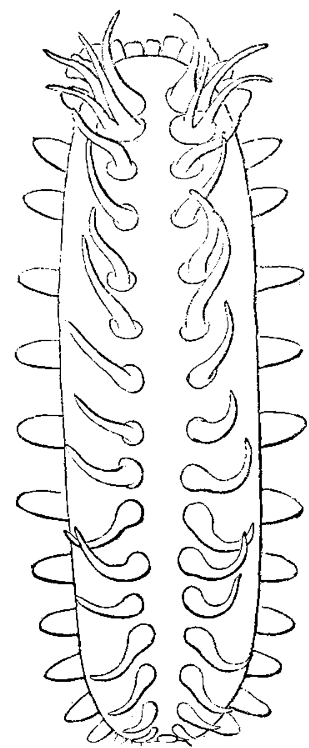

FIG. 5.-Cryodora spongrosa, Thèel. Dorsal surface.

each of its ambulacra. Integument spongy without calcareous deposits.

C. spongiosa, n.sp.

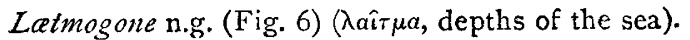

Back highly convex ; ventral surface slightly so. Mouth anterior, terminal, subventral; anus posterior, terminal, slightly dorsal. Tentacles fifteen. The lateral ambulacra of the trivium with large, not retractile, only a little contractile pedicels, disposed in a single row all along each side of the ventral surface. The odd ambulacrum

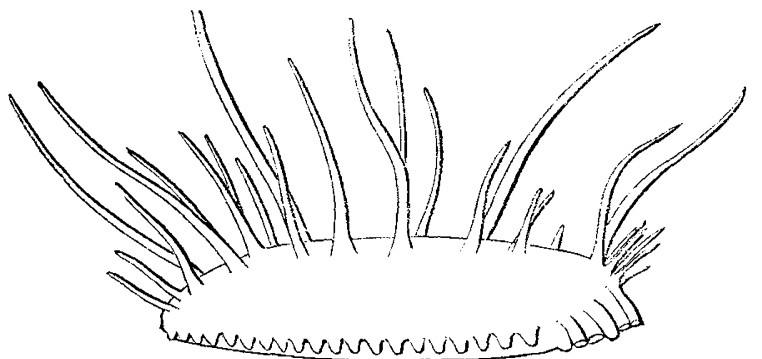

Fig. 6.- Latmogone wyville-thomsoni, théel. Side vew.

naked. Bivium with highly elongated, flexible, cylindrical, not retractile processes, disposed in a single row all along each of its ambulacra. Integument with numerous wheelshaped plates and other calcareous secretions.

L. wyville-thomsoni, n.sp.; L, violaced, n.sp.

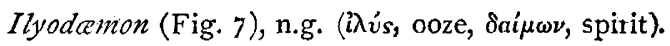

Back highly convex; ventral surface nearly flat. Mouth anterior, almost ventral; anus posterior, terminal, subdorsal. Tentacles fifteen. The lateral ambulacra of the trivium with large, not retractile pedicels, apparently disposed in a double row all along each side of the ventral surface. The odd ambulacrum naked. Bivium with a crowded series of very numerous, completely retractile, slender, rather long frocesses, disposed in three or four irregular close-set rows all along each of its ambulacra. Integument with numerous wheel-shaped plates and dichotomously branched bodies.

L. maculatus, n.sp.
Achlyonice n.g. (Fig. 8) (ả $\lambda \lambda$ ís, darkness).

Back highly convex; ventral surface flat or almost concave. Mouth anterior, ventral; anus posterior, dorsal. Tentacles twelve. The lateral ambulacra of the trivium with more or less retractile pedicels, disposed in

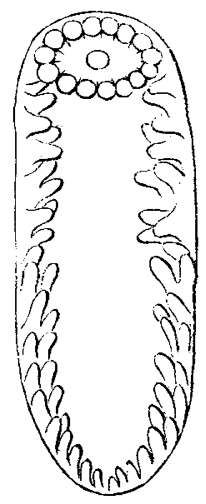

Eis. 7 .

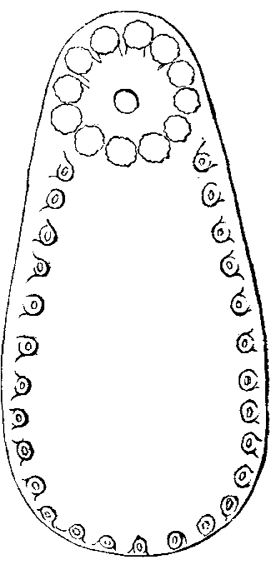

Fig. 8.
Fig. 7.-Ilyodamon naculatus, Théel. Ventral surface, FiG. 8.Achlyonice ecalcarea, Théel. Ventral surface.

a single row all along each side of the ventral surface. The odd ambulacrum naked. Bivium with a few very soft and flexible processes in its anterior part alone. Integument thick, spongy, destitute of calcareous deposits. A. ecalcarea, n.sp.

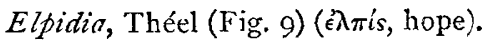

"Mémoire sur lElpidia," $K$. Sv. Vet.-Akad. Handl., Bd. I4, No. 8, 1877.

Body ovate, more or less elongated, sometimes cylindrical. Mouth anterior, terminal, or subventral, anus posterior, terminal, subventral, or subdorsal. Tentacles ten. The lateral ambulacra of the trivium with large, slightly retractile fedicels, disposed in a single row along

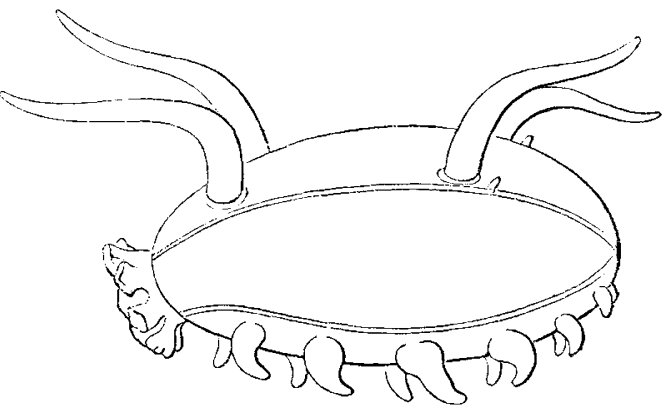

Fic. 9.-Elpidia globosa, Théel. Side view.

each side of the ventral surface. The odd ambulacrum naked. Bivium with one or a few pairs of often very elongated, not retractile processes on each of its ambulacra, or with only a few more or less rudimental ones in its anterior part. Integument with spicula of various shapes.

E. glacialis, Théel. E. mollis, n.sp.

$E$. vermicosa, n.sp. E. nana, n.sp.

E. murrayi, n.sp. E. papillosa, n.sp. E. elongata, n.sp.

Irpa, K. and D. (Fig. Io) (from the Norse mythology).

Body nearly cylindrical, bilateral. Mouth nearly central, anal ofening terminal. Ten short, thick, digitate tentacles. Along the sides of the body nine pairs of long, 
stiff, non-retractile pedicels, and six round the posterior end of the body. On the back two rows of papilla, and

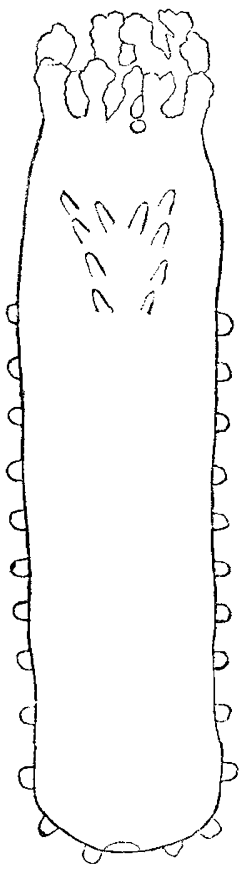

Fig. ro.

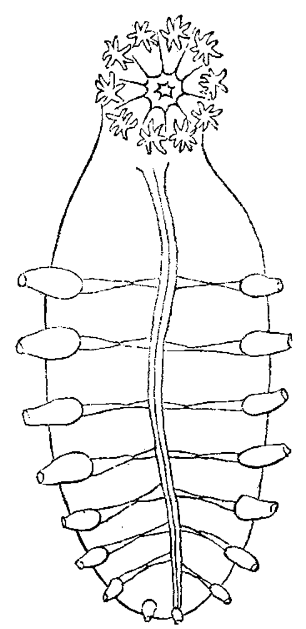

Frg. $1 x$.
Fig. 10-Irpa abyssicola, K. and D, Dorsal surface, FIG. I1.-Kolga hyalina, $\mathrm{K}$. and $\mathrm{D}$. Ventral surface.

two standing separate between them. Calcareous spicules in the skin.

L. abyssicola, $\mathrm{K}$. and $\mathrm{D}$.

Kolga, K. and D. (Fig. II) (from the Norse mythology).

Body bilateral; oral disk furnished with ten tentacles, turned towards the ventral surface. On the anterior portion of the back there is a prominent collar furnished with papillæ, and right in front of it two openings, a genital opening and the opening of the sand canal. Pedicels on both sides of the body and round the posterior end. Sexes separate. No "respiratory tree."

$K$. hyalina, K. and $\mathrm{D}$.

These are all abyssal forms, eight of the seventeen species having been dredged from depths of more than 2,000 fathoms. They are very extravagant in shape-the names which Dr. Théel has given them shows that their appearance suggests such stuff as dreams are made onand they are of large size, some over a foot in length.

One group is very gelatinous, and of a rich purple colour ; others are gelatinous, grey, and semi-transparent ; while another series, and among these the most fantastic of the whole, are yellowish and have a test crustaceous with a thick layer of calcareous plates, often running out into strangely shaped processes. A peculiar little group from the Antarctic Sea are little more than a gelatinous membrane, covering an enormously distended intestine, filled with diatom ooze. From the number of species and individuals which came up in our scattered and in. frequent hauls of the trawl, the Elasmopoda must form quite a prominent feature of the abyssal fauna.

\section{WYVILLE THOMSON}

\section{NOTES}

A HIGH and well-deserved compliment has been paid to the United States Signal Service, of whose services to meteorology our readers are so well aware. The German Government recently addressed through the German Minister at Washington, a letter requesting to be exactly informed as to the processes by which the Signal Service Bureau so promptly collects at the War Department the meteorological reports from all parts of the United States-an extent of territory greater than Europe---and so rapidly drafts and publishes them upon the printed daily weather map. These maps are issued three hours after the records are read at the distant stations. When it is remembered that the request comes from a government noted for its skilled. chartographers, and standing first in Europe, the value of the compliment will be appreciated. It is understood that the German Government proposes an advance in meteorological work. The information sought has been minutely prepared by the Chief Signal Officer, Gen. Myer, with the approval of the Secretary of War.

THE death is announced of Mr. Thomas Bell, F.R.S., F.L.S., \&c., of the Wakes, Selborne, Hampshire, on Saturday, at the advanced age of eighty-seven. Mr. Bell had a large practice as a dentist, and his name was well known in the scientific world. He was for a long period Professor of Zoology in King's College, and his histories of "British Quadrupeds" and of "British Reptiles," though published more than forty years ago, are still much esteemed. When he was over eighty-four years old he brought out his edition of Gilbert White's "Natural History of Selborne." Mr Bell was Corresponding Member of several foreign scientific societies. About eighteen years ago he gave up practice and retired to The Wakes at Selborne, Gilbert White's bouse, which he purchased from the great-nieces of the naturalist. Here he collected every memorial he could find of White, and the house and grounds were ever open to the admirers of "The Selborne."

The Paris Academy of Sciences has received information of the death of M. Zinin, the eminent chemist, of St. Petersburg. He was the discoverer of the production of aniline colours by hydro-carburets.

THE University of Königsberg lost towards the close of last month one of the oldest members of its professorial staff, in the person of Dr. Ludwig Moser, Professor of Physics. Long before photography had become a practical art, Dr. Moser had acquired considerable reputation by his systematic and successful experiments in this department. He was in his seventy-fifth year.

THE following epigram on Dr. Siemens's recent paper has been sent us as by "a well-known scientific man." It is entit'ed Electric Chlorophyll :--

"Quis veterum vidit plantas sine sole virentes Germinat en semen Siementis lumine claro."

THE Ancient Monuments' Bill has been read a second time in the House of Lords and been referred to a Select Committee.

Her Majesty has been graciously pleased to command that the Agricultural College, Cirencester, be styled the "Royal Agricultural College."

M. MASCART, the head of the French Central Bureau of Meteorology, has sent out a circular to his several rural corre spondents, with forms for the purpose of collecting information on a number of natural phenomena relating to animal and plant life.

IT appears that the Berlin Municipal Corporation has granted to Dr. W. Siemens the concession of one electrical railway which will connect Wedding.Platz with Belle Alliance.Platz. The rails will be supported by iron columns, which will not be an obstruction for the circulation of carriages and passengers in the streets. There will be no intermediate station between the two termini. 